\title{
Pengaruh jumlah penduduk dan inflasi serta investasi swasta terhadap pertumbuhan ekonomi
}

\author{
Kuswati Indra Rahayu ${ }^{1}$, Michael ${ }^{2}$, Siti Amalia ${ }^{3}$ \\ Magister Ilmu Ekonomi, Fakultas Ekonomi dan Bisnis Universitas Mulawarman, Samarinda. \\ ${ }^{1}$ Email: kuswati.indra.rahayu@mhs.feb.unmul.ac.id \\ ${ }^{2}$ Email: michael@feb.unmul.ac.id \\ 33Email: siti.amalia@feb.unmul.ac.id
}

\begin{abstract}
Abstrak
Penelitian ini bertujuan untuk mengetahui pengaruh jumlah penduduk, inflasi, dan investasi swasta terhadap pertumbuhan ekonomi dan pengangguran di Provinsi Kalimantan Timur, baik secara langsung maupun secara tidak langsung. Penelitian ini bersifat eksplanatif (eksplanatory research), yakni berusaha menjelaskan hubungan kausalitas (causality relationship) antara jumlah penduduk, inflasi, dan investasi swasta terhadap pengangguran melalui pertumbuhan ekonomi di Provinsi Kalimantan Timur dengan menggunakan data panel, tahun 2003-2014 di 9 kabupaten/ kota. Model analisis yang digunakan dalam penelitian ini adalah structural equation model (SEM). Hasil penelitian menunjukkan bahwa jumlah penduduk secara langsung berpengaruh signifikan terhadap pertumbuhan ekonomi Kalimantan Timur, sedangkan inflasi dan investasi swasta secara langsung tidak berpengaruh signifikan terhadap pertumbuhan ekonomi Kalimantan Timur. Kemudian, Pertumbuhan ekonomi, inflasi dan investasi swasta secara langsung tidak berpengaruh signifikan terhadap pengangguran di Kalimantan Timur. Sedangkan jumlah penduduk secara langsung berpengaruh signifikan terhadap pengangguran di Kalimantan Timur. Selanjutnya, jumlah penduduk, inflasi dan investasi swasta secara tidak langsung tidak berpengaruh signifikan terhadap pengangguran di Kalimantan Timur.
\end{abstract}

Kata Kunci: Jumlah penduduk; inflasi; investasi swasta;

\section{Influence of population and inflation and private investment on economic growth}

\begin{abstract}
This study aims to determine the effect of population, inflation, and private investment to economic growth and unemployment in the province of East Kalimantan, either directly or indirectly. This research is an explanatory, which seeks to explain causality between the number of population, inflation, and private investment to unemployment through economic growth in the province of East Kalimantan using panel data, years 2003 to 2014 in nine districts / cities. Analysis model used in this study is the structural equation modeling (SEM). The results showed that the number of direct significant effect on economic growth in East Kalimantan, while inflation and direct private investment has no significant effect on the economic growth of East Kalimantan. Then, economic growth, inflation and direct private investment has no significant effect on unemployment in East Kalimantan. While the number of people directly significant effect on unemployment in East Kalimantan. Furthermore, the number of population, inflation and private investments indirectly no significant effect on unemployment in East Kalimantan.
\end{abstract}

Keywords: Population; inflation; private investment; economic growth 


\section{PENDAHULUAN}

Pengangguran merupakan fenomena yang terjadi di semua negara berkembang tidak terkecuali di Indonesia. Pengangguran merupakan satu dari beberapa masalah penting yang pasti dihadapi oleh perekonomian negara maju maupun negara yang sedang berkembang karena dampak tingkat pengangguran yang tinggi tidak hanya mengganggu stabilitas ekonomi tetapi juga keamanan dan stabilitas politik.

Dalam beberapa literatur dinyatakan bawa pengangguran adalah keadaan yang dialami seseorang yang tergolong dalam angkatan kerja ingin mendapatkan pekerjaan tetapi belum dapat memperolehnya (Sukirno, 2006:13). Pengangguran dialami penduduk yang sedang mencari pekerjaan, atau mempersiapkan suatu usaha atau merasa tidak mungkin mendapatkan pekerjaan atau sudah punya pekerjaan tetapi belum mulai bekerja (BPS, 2010).

Menyediakan kesempatan kerja yang sesuai dengan jumlah tenaga kerja yang sesuai dengan jumlah tenaga kerja yang tersedia, merupakan tanggung jawab penting perekonomian suatu negara. Dalam perekonomian yang bersifat Laizzer-faire atau dalam sistem perekonomian yang bersifat bebas, tanggung jawab itu terutama berada di sektor swasta. "Semakin berkembang sektor swasta, semakin tinggi kesempatan kerja yang akan diciptakan oleh sektor tersebut" (Sukirno, 2000: 8). Selanjutnya adanya tingkat pengangguran menyebabkan kemakmuran masyarakat menjadi berkurang (Suyuthi, 1989:139).

Persentase pengangguran terbuka di Kalimantan Timur masih berada di atas rata-rata nasional yakni sebesar 7,94 persen pada tahun 2013, sedangkan persentase pengangguran rata-rata nasional adalah 6,25 persen pada tahun yang sama. Hal ini menyebabkan tingkat pengangguran masih menjadi masalah utama (Asmalyah, 2014).

Pemerintah Provinsi Kalimantan Timur dengan kebijakannya di sektor ketenagakerjaan selalu berupaya mengurangi angka tingkat pengangguran dengan program prioritas pada 2014-2018, yaitu membuka sekitar 150 ribu lapangan pekerjaan di berbagai sektor, baik pertanian dalam arti luas, eksisting industri perekonomian Kalimantan Timur di masa mendatang (Asmalyah, 2014).

Provinsi Kalimantan Timur yang mempunyai kemampuan sumber daya manusia yang cukup banyak untuk dikembangkan, di lain pihak dihadapkan dengan berbagai kendala khususnya di bidang ketenagakerjaan, seperti perkembangan jumlah angkatan kerja yang pesat namun tidak diikuti tersedianya lapangan pekerjaan yang cukup.

\section{Kajian Pustaka}

\section{Kesempatan Kerja dan Pengangguran}

Menurut Badan Pusat Statistik (BPS), pengangguran adalah istilah untuk orang yang tidak bekerja sama sekali, sedang mencari kerja, bekerja kurang dari dua hari selama seminggu, atau seseorang yang sedang berusaha mendapatkan pekerjaan. Data pengangguran dikumpulkan BPS melalui survei rumah tangga, seperti Survei Angkatan Kerja Nasional (Sakernas), Sensus Penduduk (SP), Survei Penduduk Antar Sensus (SUPAS), dan Survei Sosial Ekonomi Nasional (Susenas). Di antara sensus/survei tersebut Sakernas merupakan survei yang khusus dirancang untuk mengumpulkan data ketenagakerjaan secara periodik. Saat ini Sakernas diselenggarakan dua kali setahun yaitu pada bulan Februari dan Agustus.

Adapun jenis-Jenis pengangguran menurut Sukirno (2008: 328-331) berdasarkan penyebabnya terbagi menjadi (1) Pengangguran friksional, adalah pengangguran normal yang terjadi jika ada 2-3\% maka dianggap sudah mencapai kesempatan kerja penuh; (2) Pengangguran siklikal, adalah pengangguran yang terjadi karena merosotnya harga komoditas dari naik turunnya siklus ekonomi sehingga permintaan tenaga kerja lebih rendah dari pada penawaran tenaga kerja; (3) Pengangguran Struktural, adalah pengangguran karena kemerosotan beberapa faktor produksi sehingga kegiatan produksi menurun dan pekerja diberhentikan; dan (4) Pengangguran Teknologi, adalah pengangguran yang terjadi karena tenaga manusia digantikan oleh mesin industri.

Berdasarkan cirinya pengangguran terbagi menjadi: (1) Pengangguran musiman, adalah keadaan seseorang menganggur karena adanya fluktuasi kegiatan ekonomi jangka pendek. Sebagai contoh, 
petani yang menanti musim tanam, tukang jualan durian yang menanti musim durian, dan sebagainya; (2) Pengangguran Terbuka, pengangguran yang terjadi karena pertambahan lapangan kerja lebih rendah daripada pertambahan pencari kerja; (3) Pengangguran Tersembunyi, pengangguran yang terjadi karena jumlah pekerja dalam suatu kegiatan ekonomi lebih besar dari yang sebenarnya diperlukan agar dapat melakukan kegiatannya dengan efisien; dan (4) Setengah Menganggur, yang termasuk golongan ini adalah pekerja yang jam kerjanya di bawah jam kerja normal (hanya 1-4 jam sehari) disebut under-employment.

Mengenai konsep angkatan kerja menurut Manurung (2004: 173) terbagi menjadi: (1) Bekerja Penuh (Employed), yaitu orang-orang yang bekerja penuh atau jam kerjanya lebih dari $35 \mathrm{jam} /$ minggu; (2) Setengah menganggur (Underemployed), yaitu mereka yang bekerja, tetapi belum dimanfaatkan secara penuh. Jam kerjanya kurang dari $35 \mathrm{jam} /$ minggu. Berdasarkan definisi ini, tingkat pengangguran di Indonesia termasuk tinggi, yaitu $35 \%$ per tahun; dan (3) Menganggur (Unemployed), yaitu mereka yang sama sekali tidak bekerja atau sedang mencari pekerjaan. Kelompok ini sering disebut Penganggur Terbuka (Open Unemployment). Berdasarkan definisi ini, tingkat pengangguran di Indonesia relatif rendah, yaitu 3-5\% per tahun.

\section{Pertumbuhan Ekonomi Klasik}

Teori pertumbuhan ekonomi didefinisikan sebagai penjelasan mengenai faktor-faktor yang menentukan kenaikan output per kapita dalam jangka panjang dan penjelasan mengenai bagaimana faktor-faktor tersebut berinteraksi satu sama lain, sehingga terjadi proses pertumbuhan. Jadi teori pertumbuhan ekonomi tidak lain adalah penjelasan logis mengenai proses pertumbuhan ekonomi terjadi pada perekonomian suatu negara.

Pertumbuhan ekonomi berkaitan erat dengan kenaikan output per kapita dan ada dua sisi yang perlu diperhatikan, yaitu output total (GDP) di satu sisi, dan jumlah penduduk di sisi lainnya.

Dalam kaitannya dengan penelitian ini akan diuraikan beberapa teori pertumbuhan ekonomi kelompok teori "mahzab analitis" dan "mahzab historis", yaitu teori pertumbuhan klasik, neo-klasik serta teori pertumbuhan modern.

\section{Teori Pertumbuhan Klasik}

\section{1) Adam Smith}

Adam Smith dengan teori nilainya, yaitu teori yang menyelidiki faktor-faktor yang menentukan nilai atau harga suatu barang. Dalam bukunya An Inquiry into the Nature and Causes of the Wealth of Nations (1776) yang disingkat Wealth of Nations mengenai bagaimana perekonomian tumbuh secara sistematis dalam jangka panjang. Teori ini sebagai awal dari pengkajian masalah pertumbuhan secara sistematis.

\section{2) David Ricardo}

Teori pertumbuhan ekonomi pada masa David Ricardo mengalami perkembangan. Perkembangan ini berupa penjabaran model pertumbuhan menjadi suatu model yang lebih komprehensif, baik dalam konsep yang dipakai maupun dalam hal mekanisme proses pertumbuhan itu sendiri.

Proses pertumbuhan Ricardo secara lebih terinci dijabarkan sebagai berikut: Pertama, tanah terbatas jumlahnya. Kedua, tenaga kerja yang meningkat atau menurun sesuai dengan tingkat upah di atas atau di bawah tingkat upah minimal. Ketiga, akumulasi capital terjadi apabila tingkat keuntungan yang diperoleh pemilik capital berada di atas tingkat keuntungan minimal yang diperlukan untuk menarik investor melakukan investasi. Keempat, dari waktu ke waktu terjadi kemajuan teknologi, dan Kelima, dominannya sektor pertanian.

Menurut David Ricardo bahwa:

"Faktor akumulasi kapital dan teknologi cenderung meningkatkan produktivitas tenaga kerja, artinya bisa memperlambat bekerjanya The Law of Diminishing Return, sehingga memperlambat pula penurunan tingkat hidup ke arah tingkat hidup minimal, meskipun antara akumulasi kapital dan teknologi memiliki peranan yang berbeda. Akumulasi kapital hanya akan dilakukan apabila kapital 
menerima imbalan (keuntungan) yang cukup. Kemajuan teknologi meningkat produktivitas tenaga kerja dan produktivitas kapital (Boediono, 1999: 19)".

\section{Pertumbuhan Ekonomi Neo-Klasik Solow-Swan}

Robert Solow dari MIT dan Trevor Swan dari Australian National University secara sendirisendiri mengembangkan model pertumbuhan ekonomi yang sekarang sering disebut dengan nama "model pertumbuhan neo-klasik. Dalam model neo-klasik Solow dan Swan menggunakan suatu fungsi produksi yang lebih umum, yang bisa menampung berbagai kemungkinan substitusi antara kapital (K) dan tenaga kerja (L). Bentuk fungsi produksi ini adalah:

\section{$\mathbf{Q}=\mathbf{A F}(\mathbf{K}, \mathbf{L})$}

Fungsi tersebut menghubungkan output total $\mathrm{Q}$ dengan kegunaan ekonomis dari Kapital (K) dan Labor (L) dan dengan produktivitas (A).

Model pertumbuhan Solow sebenarnya dirancang untuk menunjukkan bagaimana pertumbuhan dalam persediaan modal, pertumbuhan dalam angkatan kerja, dan kemajuan teknologi berinteraksi dalam perekonomian dan bagaimana pengaruhnya terhadap output total barang dan jasa suatu negara. Dinamika model Solow menganggap perekonomian sebagai suatu yang mengalami perkembangan sepanjang waktu (Waluyo, 2006:188-189).

\section{Teori Pertumbuhan Modern}

\section{1) Arthur Lewis}

Model Lewis terkenal dengan nama "model pertumbuhan dengan suplai tenaga kerja yang tak terbatas". Pokok permasalahan yang dikaji oleh Lewis adalah bagaimana proses pertumbuhan terjadi dalam perekonomian dua sektor. Pertama, sektor tradisional dengan produktivitas rendah dan sumber tenaga kerja yang melimpah. Kedua, sektor moderen dengan produktivitas tinggi dan sebagai sumber akumulasi kapital. "Proses pertumbuhan ekonomi terjadi apabila tenaga kerja bisa dipertemukan dengan kapital" (Boediono, 1999: 35).

\section{2) Joseph Shumpeter}

Meskipun teori Schumpeter dapat dikelompokkan dalam teori pertumbuhan ekonomi klasik, namun pokok pikirannya lebih dekat dengan pemikiran para ekonom "moderen". Schumpeter tidak terlalu menekankan pada aspek pertumbuhan penduduk maupun aspek keterbatasan sumber daya alam dalam proses pertumbuhan ekonomi, tetapi lebih optimis pada kemampuan teknologi (inovasi) dalam mendorong pertumbuhan ekonomi.

Ada lima macam kegiatan ekonomi yang oleh Schumpeter dimasukkan sebagai inovasi. Pertama, diperkenankannya produk baru yang sebelumnya tidak ada. Kedua, diperkenankannya cara berproduksi baru. Ketiga, pembukaan daerah-daerah pasar baru. Keempat, penemuan sumber-sumber bahan mentah baru, dan Kelima, perubahan organisasi industri, sehingga meningkatkan efisiensi industri.

Menurut Schumpeter "the capitalist process, not by coincidence by virtue of its mechanism, progressively raises the standard of life for the masses". Jadi jelas bahwa kesimpulan Schumpeter bertolak belakang dengan kesimpulan pesimistis dari ekonom-ekonom yang meramalkan "stationary state". Teori Schumpeter menegaskan bahwa sumber kemajuan ekonomi adalah daya kreasi manusia pelakunya, dan bukan sekedar akumulasi kapital atau pertumbuhan penduduk.

\section{3) Harrod-Domar}

Teori pertumbuhan ekonomi Harrod-Domar adalah perkembangan langsung teori makro Keynes jangka pendek menjadi suatu teori makro jangka panjang. Aspek utama yang dikembangkan dari teori Keynes adalah aspek yang menyangkut peranan investasi dalam jangka panjang. Menurut HarrodDomar, pengeluaran investasi tidak hanya berpengaruh (lewat multiplier) terhadap permintaan agregat, tetapi juga terhadap penawaran agregat melalui pengaruhnya terhadap kapasitas produksi. Dalam 
perspektif ini investasi menambah stok capital. Ini berarti pula peningkatan kapasitas produksi masyarakat.

Dalam model Harrod-Domar, output dan kapital, output dan tenaga kerja masing-masing dihubungkan oleh suatu fungsi produksi dengan koefisien yang tidak bisa berubah, yaitu $\mathrm{Qp}=\mathrm{hK}$ dan $\mathrm{Qn}=\mathrm{nN}$.

Harrod-Domar menuliskan hubungan yang sederhana antara K dan Qp sebagai berikut:

$$
\mathbf{Q p}=\mathbf{h K}
$$

Di mana $\mathrm{h}$ menunjukkan jumlah unit output yang bisa dihasilkan dari setiap unit capital. Koefisien ini diberi nama Output -Capital Ratio (OCR), dan kebalikannya, yaitu 1/h adalah Capital Output Ratio (COR).

Dari beberapa uraian sebelumnya dapat dijelaskan kembali bahwa dalam perekonomian makro pertumbuhan ekonomi merupakan satu dari beberapa indikator yang sangat penting dalam melakukan analisis tentang pembangunan dan perencanaan pembangunan ekonomi yang terjadi pada suatu Negara dan daerah.

Pertumbuhan ekonomi menunjukkan hasil akhir dari aktivitas perekonomian dalam jangka panjang yang menghasilkan tambahan pendapatan masyarakat karena pada dasarnya aktivitas perekonomian yang dalam prosesnya menggunakan faktor-faktor produksi (input). Input inilah sebagai sumber peretumbuhan ekonomi.

Dalam literatur ekonomi, sumber fundamental penentu pertumbuhan ekonomi ada 4 (empat), yaitu: 1) pertumbuhan dalam labor force, 2) pertumbuhan dalam human capital, 3) pertumbuhan dalam physical capital, dan 4) technological improvement and innovation (Lipsey, Ragan dan Storer, 2008: 633-634).

\section{METODE}

Berdasarkan kerangka konsep yang dikonstruk dalam penelitian ini dan rancangan penelitian yang dibangun, maka analisis data dalam penelitian ini menggunakan metode analisis jalur (path analysis method). Penggunaan metode analisis ini memungkinkan peneliti dapat menguji beberapa variabel endogen sekaligus dengan variabel eksogen (Ferdinand, 2002: 2).

Permodelan dengan menggunakan metode analisis jalur (path analysis method) dalam penelitian ini di arahkan untuk menguji hipotesis $1,2,3,4,5,6,7,8$, 9, dan hipotesis 10 .

Dalam permodelan metode analisis jalur (path analysis method), peneliti berpijak pada constructs atau factors berdasarkan konsep-konsep yang memiliki pijakan teoretis. Konsep tersebut adalah: (1) konstruk eksogen (exsogenous constructs) yang dikenal sebagai source variable atau independent variables yang tidak diprediksi oleh variabel lain dalam model, dan (2) konstruk endogen (endogenous constructs) yang dapat memprediksi satu atau beberapa konstruk endogen lainnya.

Secara diagramatis konstruk eksogen berbentuk kontruk-konstruk yang dituju oleh garis dengan satu ujung panah. Konstruk ini hanya dapat berhubungan kausal dengan konstruk endogen. Berdasarkan pijakan teoretis yang cukup, peneliti akan memilih variabel yang dapat dimasukkan sebagai konstruk variabel endogen dan variabel eksogen.

Konstruk variabel endogen dan variabel eksogen yang dimaksud secara diagramatis dapat digambarkan sebagai berikut:

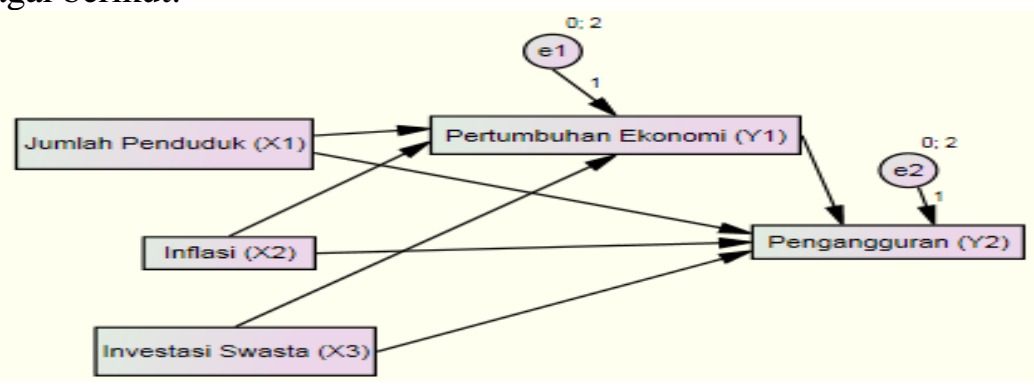

Gambar 1. Model Analisis Jalur 


\section{HASIL DAN PEMBAHASAN}

Dalam bagian ini dilakukan pemaparan yang mencakup penalaran hasil penelitian baik secara teoritis, empiris maupun nonempiris, sehingga dapat menjawab sekaligus menjelaskan rumusan masalah yang diajukan pada B1. Dalam bab ini juga dilakukan perpaduan temuan penelitian dengan hasil penelitian terdahulu dan konsekuensi serta pengembangannya di masa yang akan datang. Di samping itu, dalam bab ini juga dilakukan temuan konsep yangt dihasilkan dari penelitian ini serta pemahaman terhadap keterbatasan penelitian yang dilakukan sehingga dapat memberikan saran bagi penelitian selanjutnya.

Berdasarkan hasil analisis ditemukan bahwa secara langsung jumlah penduduk berpengaruh signifikan terhadap pertumbuhan ekonomi dan pengangguran, namun secara tidak langsung pengaruhnya tidak signifikan terhadap pengangguran.

Mengacu pada teori Adam Smith yang menyatakan bahwa manusia merupakan faktor produksi utama yang menentukan kemakmuran bangsa. Adam Smith juga melihat bahwa alokasi sumber daya manusia adalah pemula pertumbuhan ekonomi. Adam Smith beranggapan bahwa pertumbuhan ekonomi bertumpu pada adanya pertumbuhan penduduk. Dengan adanya pertumbuhan penduduk maka akan terdapat pertambahan output dan pertambahan hasil (Christiawan et al, 2015).

Teori ini didukung oleh Sukirno (2010; 429), bahwa Penduduk yang bertambah dari waktu ke waktu dapat menjadi pendorong bahkan penghambat suatu pertumbuhan ekonomi. Dorongan yang timbul dari perkembangan penduduk terhadap pertumbuhan ekonomi bersumber dari akibat pertambahan luas pasar. Perkembangan penduduk menyebabkan besarnya luas pasar dari barangbarang yang dihasilkan perusahaan menjadi besar pula. Maka perkembangan penduduk akan menimbulkan dorongan kepada pertambahan dalam produksi nasional dan tingkat kegiatan ekonomi. Akibat buruk dari pesatnya pertambahan penduduk kepada pertumbuhan ekonomi terutama dihadapi oleh masyarakat yang kemajuan ekonominya belum tinggi tetapi telah menghadapi masalah kelebihan penduduk. Suatu negara dipandang menghadapi masalah kelebihan penduduk apabila jumlah penduduk tidak seimbang dengan faktor-faktor produksi lain yang tersedia.

Hasil penelitian ini tidak mendukung teori Adam Smith, hal ini disebabkan kondisi penduduk Provinsi Kaltim terlihat bahwa pada kelompok usia muda proporsi tenaga kerja relatif lebih besar dan semakin meningkatnya umur terlihat proporsi tenaga kerja semakin menurun. Kondisi ini terjadi di samping karena adanya kematian juga karena struktur umur penduduk Kalimantan Timur masih tergolong dalam kategori intermediate population atau sedang bergeser dari penduduk muda ke arah penduduk tua sehingga berpengaruh terhadap produktivitas dalam kontribusinya terhadap pertambahan output di Kaltim.

Selain itu, jika mencermati kualitas penduduk dari sudut pendidikan maka terlihat penduduk yang tamat SLTA memiliki proporsi terbesar dibandingkan yang lain yaitu mencapai 33,16 persen, disusul kemudian mereka yang tamat SLTP yaitu 23,50 persen dan tamat SD sebesar 21,44 persen. Masih tingginya proporsi penduduk pada kelompok tamat SD ke bawah perlu menjadi perhatian serius oleh pemerintah dalam upaya pembangunan di bidang pendidikan, guna meningkatkan kualitas sumber daya manusia yang ada di daerah ini. Sebab semakin tinggi tingkat pendidikan tenaga kerja dapat diasumsikan kualitas tenaga kerja tersebut semakin baik, karena semakin tinggi tingkat pendidikan diperkirakan kemampuan dan keterampilan mereka akan bertambah. Hal ini tentu dapat meningkatkan pertambahan output di Kaltim.

Penyebab lainnya yang menyebabkan jumlah penduduk menurunkan pertumbuhan ekonomi adalah tingkat partisipasi angkatan kerja Kalimantan Timur relatif lebih rendah bila dibandingkan TPAK provinsi-provinsi lain yaitu rata-rata 64,10 persen dibandingkan dengan total penduduk di Provinsi Kaltim.

Hasil penelitian ini tidak mendukung hasil penelitian yang di lakukan oleh Christiawan et al, (2015) yaitu jumlah penduduk memiliki pengaruh positif dan signifikan terhadap pertumbuhan ekonomi di Kabupaten Jember. 
Berdasarkan hasil analisis ditemukan bahwa secara langsung pengaruh inflasi terhadap pertumbuhan ekonomi dan pengangguran tidak signifikan. Demikian pula secara tidak langsung inflasi tidak berpengaruh signifikan terhadap pengangguran..

Inflasi merupakan salah satu indikator penting dalam pengendalian ekonomi makro yang berdampak luas terhadap berbagai sektor ekonomi. Sebagian ahli ekonomi berpendapat bahwa inflasi yang sangat lambat berlakunya dipandang sebagai stimulator bagi pertumbuhan ekonomi. Jadi jika inflasi terjadi secara berkepanjangan tentunya akan berpengaruh terhadap pertumbuhan ekonomi karena kebanyakan orang ingin menyimpan uangnya saja di Bank tanpa berpikir untuk berinvestasi yang di mana investasi merupakan faktor yang paling menunjang bagi pertumbuhan ekonomi. Akan tetapi jika inflasi hanya berlangsung sementara dan tingkat inflasi yang masih di batas wajar dengan syarat dan batas-batas yang masih toleran justru inflasi akan mendorong perekonomian. Laju inflasi yang terlalu tinggi dapat mengganggu usaha pemerintah meningkatkan taraf hidup masyarakat (Putong, 2003:254).

Di satu sisi, inflasi Kalimantan Timur tahun 2014 ditandai dengan besaran yang lebih rendah dibanding dengan inflasi nasional sejak tahun 2007. Inflasi di tahun 2014 menunjukkan nilai yang lebih rendah dibandingkan dengan tahun sebelumnya yakni sebesar 9,65 persen. Komposisi inflasi Kalimantan Timur didominasi oleh kelompok barang yang terpengaruh kebijakan pemerintah, yakni kelompok transportasi, komunikasi dan jasa keuangan yang didorong oleh kenaikan harga BBM bersubsidi, serta kelompok perumahan, air, listrik, gas dan bahan bakar yang didorong oleh kenaikan tarif listrik dan harga LPG. Selain itu kenaikan pada kelompok bahan makanan juga menyumbang relatif tingginya inflasi Kalimantan Timur.

Di sisi lain, pertumbuhan ekonomi Kalimantan Timur pada tahun 2014 berada dalam tren melambat, karena dipengaruhi oleh kondisi global yang tidak sesuai harapan serta komoditi andalan ekspor Kalimantan Timur yang mengalami penurunan harga di pasar global. Hal ini disebabkan struktur ekonomi Kalimantan Timur masih bertumpu pada ekspor komoditas berbasis Sumber Daya Alam (SDA), ditambah dengan ekonomi dan kebijakan negara tujuan ekspor yang kurang kondusif sehingga kinerja ekspor melambat. Negara tujuan ekspor Kalimantan Timur utamanya adalah Jepang, Korea, Cina dan India.

Ekonomi global yang melambat dan diiringi oleh harga komoditas global yang menurun mendorong perbaikan kinerja ekspor riil menjadi tidak terlalu kuat. Selain bersumber dari perlambatan ekspor, perlambatan ekonomi juga disebabkan oleh stimulus fiskal dalam perekonomian yang menurun sejalan dengan program penghematan belanja yang ditempuh Pemerintah. Ekspor yang melemah dan program penghematan belanja Pemerintah ini pada gilirannya akan menurunkan pendapatan rumah tangga, sehingga konsumsi rumah tangga juga ikut mengalami perlambatan.

Sehingga dapat disimpulkan bahwa inflasi tidak berpengaruh terhadap pertumbuhan ekonomi di Provinsi Kaltim karena inflasi yang terjadi pada sektor transportasi, komunikasi dan jasa keuangan dan sektor perumahan, air, listrik, gas dan bahan bakar serta sektor industri pengolahan. Sedangkan sektor ekonomi yang berkontribusi besar terhadap pertumbuhan ekonomi Kaltim adalah sektor pertambangan.

Hasil penelitian ini tidak mendukung hasil penelitian Rovia (2013) yang menemukan bahwa Inflasi berpengaruh positif dan signifikan terhadap pertumbuhan ekonomi di Kabupaten Trenggalek. Tapi hasil penelitian ini mendukung penelitian Akhirman (2012) yang menyatakan bahwa Inflasi tidak berpengaruh signifikan terhadap pertumbuhan ekonomi Provinsi Kepulauan Riau Tahun 2005-2010.

Kurva Philips menjelaskan hubungan antara tingkat inflasi dengan tingkat pengangguran didasarkan pada asumsi bahwa inflasi merupakan cerminan dari adanya kenaikan permintaan agregat. Dengan naiknya permintaan agregat, berdasarkan teori permintaan, permintaan akan naik, kemudian harga akan naik pula. Dengan tingginya harga (inflasi) maka untuk memenuhi permintaan tersebut produsen meningkatkan kapasitas produksinya dengan menambah tenaga kerja (tenaga kerja merupakan satu-satunya input yang dapat meningkatkan output). Akibat dari peningkatan penyerapan tenaga kerja tersebut maka dengan naiknya harga-harga (inflasi) pengangguran menjadi berkurang atau bisa dilihat pula dengan tingkat inflasi yang stabil akan menurunkan tingkat suku bunga yang 
secara langsung kemudian akan memicu banyaknya permintaan atas kredit usaha dan akan banyak industri atau sektor usaha yang bermunculan, sehingga jumlah penyerapan tenaga kerja meningkat seiring kesempatan kerja yang tinggi.

Di satu sisi, inflasi Kalimantan Timur tahun 2014 ditandai dengan besaran yang lebih rendah dibanding dengan inflasi nasional sejak tahun 2007. Inflasi di tahun 2014 menunjukkan nilai yang lebih rendah dibandingkan dengan tahun sebelumnya yakni sebesar 9,65 persen. Komposisi inflasi Kalimantan Timur didominasi oleh kelompok barang yang terpengaruh kebijakan pemerintah, yakni kelompok transportasi, komunikasi dan jasa keuangan yang didorong oleh kenaikan harga BBM bersubsidi, serta kelompok perumahan, air, listrik, gas dan bahan bakar yang didorong oleh kenaikan tarif listrik dan harga LPG. Selain itu kenaikan pada kelompok bahan makanan juga menyumbang relatif tingginya inflasi Kalimantan Timur.

Tingkat pengangguran pada Kabupaten/Kota di Provinsi Kaltim dari tahun 2003 sampai dengan tahun 2014 rata-rata sebesar 10,21 persen per tahun dengan jumlah penduduk yang meningkat rata-rata 100.000 jiwa setiap tahunnya.

Hal ini menunjukkan bahwa inflasi yang diharapkan mampu untuk mengurangi pengangguran melalui sektor riil, baik dari permintaan agregat maupun melalui sektor moneter (penurunan tingkat bunga) ternyata tidak berpengaruh terhadap penurunan pengangguran di Kaltim. Hal ini mendukung hasil penelitian Isti (2013) yang menunjukkan bahwa tingkat inflasi tidak berpengaruh terhadap pengangguran di Jawa Timur. Selanjutnya Jihad (2015) juga menemukan bahwa inflasi tidak memiliki pengaruh yang signifikan terhadap tingkat pengangguran Se-Eks Karesidenan Surakarta di Jawa Tengah tahun 1999-2013.

Dalam teori investasi dan perencanaan pembangunan ekonomi dinyatakan bahwa investas berpengaruh terhadap pertumbuhan ekonomi karena besaran pertumbuhan ekonomi tersebut erat kaitannya dengan tingkat produktivitas penggunaan modal dalam proses produksi. Hal ini dapat dijelaskan dengan melihat Incremental Capital Output Rasio ((ICOR) sebagai metode analisisnya.

Metode ICOR di samping dapat digunakan untuk menunjukkan efisiensi suatu perekonomian dalam penggunaan faktor produksi modal, ICOR juga dapat pula menunjukkan pula kecenderungan penggunaan metode produksi dalam suatu perekonomian. Sehingga dengan demikian, efisiensi penggunaan faktor produksi modal yang dikenal dengan istilah investasi (mengikuti teori aliran NeoKlasik) akan menghasilkan tingkat pertumbuhan ekonomi tertentu.

Berdasarkan hasil analisis ditemukan bahwa investasi swasta secara langsung tidak berpengaruh signifikan terhadap pertumbuhan ekonomi dan pengangguran. Demikian pula secara tidak langsung pengaruhnya tidak signifikan terhadap pengangguran..

Investasi memiliki dampak jika di arahkan untuk sektor ekonomi yang menghasilkan pertumbuhan ekonomi yang berkelanjutan dan tidak pada sektor spekulatif seperti ritel dan real estate. Dengan kata lain, berorientasi di bidang produksi tertentu, investasi akan mencipakan pekerjaan, baik langsung (di lapangan di mana investasi dilakukan) dan tidak langsung (di bidang lain, jaminan dan / atau terkait).

Investasi di bidang yang diarahkan pada faktor dominan seperti padat karya memiliki dampak yang signifikan dalam hal menciptakan lapangan kerja baru dan mengurangi pengangguran. Sebagai perbandingan, investasi yang berorientasi terhadap kegiatan didasarkan terutama pada teknologi canggih dan pengetahuan memiliki dampak kualitatif penting, mengakibatkan upah yang lebih tinggi, kondisi kerja yang lebih baik dan perbaikan terus-menerus dari tingkat pelatihan dari tenaga kerja.

Sektor yang menjadi tujuan investasi di Kalimantan Timur adalah sektor tanaman pangan dan perkebunan, sektor pertambangan, industri makanan, industri kayu, industri kimia dan farmasi, sektor listrik, air dan gas, sektor transportasi gudang dan komunikasi, dan sektor jasa lainnya.

Meskipun sektor-sektor yang menjadi tujuan investasi sebagian besar merupakan sektor padat karya, namun dalam investasi terdapat lag time antara realisasi investasi dan operasional perusahaan sehingga investasi tidak dapat langsung berpengaruh terhadap penyerapan tenaga kerja di Kaltim. Hal ini pun dapat terjadi jika diasumsikan bahwa perusahaan mengutamakan tenaga kerja yang berdomisili di Kaltim. 
Hasil penelitian ini mendukung penelitian Sucitrawati et al (2012) yang menyatakan bahwa investasi tidak berpengaruh terhadap tingkat pengangguran di Bali dan menolak hasil penelitian Mukti (2013) yang menyatakan bahwa Investasi asing berpengaruh negatif dan signifikan terhadap pengangguran Jawa Tengah tahun 1980-2011.

Menurut Keynes meningkatnya investasi akan mengakibatkan naiknya pendapatan yang kemudian akan meningkatkan pekerjaan. Jelaslah bahwa Keynes memberi peran yang cukup penting bagi keberadaan investasi dalam mengatasi ketidakseimbangan antara konsumsi dan pendapatan (Jhinghan, 2000). Pendapat ini didukung oleh Samuelson dan Nordhaus (2010) menyatakan bahwa investasi berperan penting dalam ekonomi makro yaitu mempengaruhi permintaan agregat. Selain itu investasi juga mempengaruhi daur bisnis (business cycle) serta pembentukan modal (capital accumulation). Tingkat investasi yang tinggi akan menyebabkan pembentukan modal. Jadi investasi berfungsi ganda yakni berpengaruh terhadap pendapatan nasional (output) jangka pendek melalui permintaan agregat juga terhadap pertumbuhan pendapatan nasional jangka panjang melalui dampak pembentukan atas output potensial dan penawaran agregat.

Peran penting investasi dalam permintaan agregat: pertama, biasanya pengeluaran investasi lebih tidak stabil apabila dibandingkan dengan pengeluaran konsumsi sehingga fluktuasi investasi dapat menyebabkan resesi atau boom. Oleh karena itu para ahli ekonomi sangat tertarik untuk menganalisisnya terutama kaitannya dengan kebijaksanaan stabilisasi untuk mengatasi akibat buruk dari adanya fluktuasi investasi. Kedua, bahwa investasi sangat penting bagi pertumbuhan ekonomi serta perbaikan dalam produktivitas tenaga kerja. Terkait dengan investasi yang diartikan sebagai tambahan jumlah (stock) kapital, maka memiliki pengaruh terhadap pertumbuhan ekonomi yang tergantung pada tenaga kerja dan jumlah (stock) kapital (Samuelson dan Nordhaus ;2010).

Sektor yang menjadi tujuan investasi di Kaltim adalah sektor tanaman pangan dan perkebunan, sektor pertambangan, industri makanan, industri kayu, industri kimia dan farmasi, sektor listrik, air dan gas, sektor transportasi gudang dan komunikasi, dan sektor jasa lainnya. Sedangkan struktur ekonomi Kalimantan Timur masih bertumpu pada ekspor komoditas berbasis Sumber Daya Alam (SDA). Hal ini salah satu penyebab investasi swasta tidak berpengaruh terhadap pertumbuhan ekonomi. Sebab yang lainnya dalam analisis data penelitian ini tidak ada lag time (jarak waktu) antara realisasi investasi swasta dengan pertumbuhan ekonomi.

Hasil penelitian ini mendukung penelitian Akhirman (2012) yang menyatakan bahwa investasi swasta tidak berpengaruh signifikan terhadap pertumbuhan ekonomi Provinsi Kepulauan Riau Tahun 2005-2010.

Berdasarkan hasil analisis ditemukan bahwa secara langsung pengaruh pertumbuhan ekonomi tidak signifikan terhadap pengangguran.

Menurut Arico (2003, hal. 423) pertumbuhan ekonomi yang lebih tinggi berarti mengurangi tingkat pengangguran dan meningkatkan lowongan pekerjaan. Howitt et al (1994) mengidentifikasi proses ini sebagai efek kapitalisasi. Efek ini menyatakan bahwa tingkat pertumbuhan ekonomi yang lebih tinggi akan mempengaruhi tingkat bunga efektif yang diberikan karena perbedaan antara bunga dan tingkat pertumbuhan.

Lebih lanjut Howitt et al (1994) menjelaskan peningkatan pertumbuhan ekonomi akan meningkatkan pengembalian investasi (dengan menurunkan tingkat bunga efektif), mendorong perusahaan baru untuk memasuki pasar, menyebabkan peningkatan jumlah lowongan pekerjaan dan, dengan demikian, mengurangi pengangguran.

Menurut Mulyadi (2003) minimal ada empat kebijaksanaan pokok dalam upaya peningkatan sumber daya manusia untuk memperbaiki ketenagakerjaan di suatu daerah yaitu: (1) Peningkatan kualitas hidup manusianya seperti jasmani, rohani dan keuangan. (2) Pemerataan penyebaran penduduk. (3) Memanfaatkan, mengembangkan dan menguasai IPTEK yang berwawasan lingkungan. (4) Pengembangan pranata yang meliputi kelembagaan dan perangkat hukum. Dengan peningkatan kualitas penduduk diharapkan akan mempengaruhi peningkatan kualitas serta produktivitas tenaga kerja yang tentunya berpengaruh terhadap pembangunan dan mengurangi pengangguran. 
Hasil penelitian ini mendukung penelitian Jihad (2015) yang menyatakan bahwa Jumlah penduduk memiliki efek positif yang signifikan pada tingkat pengangguran Se-Eks Karesidenan Surakarta di Jawa Tengah tahun 1999-2013. Selanjutnya penelitian Mukti (2013) juga menyatakan jumlah penduduk berpengaruh positif dan signifikan terhadap pengangguran di Jawa Tengah periode 1980-2011.

\section{SIMPULAN}

1. Pengangguran di Kaltim terjadi karena pertumbuhan penduduk lebih tinggi dibandingkan dengan pertumbuhan lapangan kerja yang ada. Salah satu faktor yang diduga menjadi penyebab terjadinya ketidakseimbangan pasar tenaga kerja tersebut adalah ketidakcocokan keinginan atau kebutuhan antara pasar tenaga kerja dengan pengguna tenaga kerja.

2. Selanjutnya disebabkan keterbatasan sektor pertambangan dalam menyerap tenaga kerja, kondisi ekonomi global yang mempengaruhi penurunan ekspor migas dan batubara serta jumlah migrasi penduduk yang besar menyebabkan pertumbuhan ekonomi tidak mampu mempengaruhi tingkat pengangguran di Kaltim. Hasil penelitian ini tidak mendukung penelitian Isti (2013) yang menyatakan bahwa Pertumbuhan ekonomi berpengaruh negatif dan signifikan terhadap pengangguran Jawa Timur.

3. Pengangguran terjadi karena pertumbuhan penduduk lebih tinggi dibandingkan dengan pertumbuhan lapangan kerja yang ada. Salah satu faktor yang diduga menjadi penyebab terjadinya ketidakseimbangan pasar tenaga kerja tersebut adalah ketidakcocokan keinginan atau kebutuhan antara pasar tenaga kerja dengan pengguna tenaga kerja. Selain itu, hal ini mengindikasikan fenomena positif di bidang pendidikan. Program pemerintah tentang pendidikan dasar 9 tahun yang mewajibkan penduduk usia sekolah untuk melanjutkan pendidikan secara langsung mengurangi jumlah pekerja anak. Program pendidikan dasar ini juga memberikan motivasi kepada masyarakat untuk melanjutkan ke jenjang pendidikan yang lebih tinggi. Karena menurut tingkat pendidikan yang ditamatkan, terlihat penduduk yang tamat SLTA memiliki proporsi terbesar dibandingkan yang lain yaitu mencapai 33,16 persen, disusul kemudian mereka yang tamat SLTP yaitu 23,50 persen dan tamat SD sebesar 21,44 persen.

\section{DAFTAR PUSTAKA}

Aricó, F. (2003); Growth and Unemployment Towards a Theoretical Integration; Journal of Economics Survey Vol. 17, No. 3, pp. 419-455;

Samuelson. Paul A \& William D Nordhaus.(2010). Mikroekonomi. Jakarta: Erlangga

BPS. 2015. Kaltim dalam Angka 2015. Pemerintah Provinsi Kalimantan Timur.

Harrod, Roy F.,1939. An Essay in Dynamic Theory. The Economic Journal 49 (193), Maret : 14-33.

Howitt, P and Aghion P. (1994), Growth and Unemployment, Review of Economic Studies, Vol. 61, No. 3, pp. 477-94;

Jhingan, 2000. Ekonomi Pembangunan dan Perencanaan, Penerjemah Guritno, Penerbit PT RajaGrafindo Persada Jakarta.

Lipsey, Ragan and Storer. (2008). Economics. 13th edition. Pearson Education, Inc.: Boston.

Manurung, Mandala dan Prathama Rahardja. 2004, Uang, Perbankan, dan Ekonomi Moneter, Jakarta: Penerbit Fakultas Ekonomi Universitas Indonesia.

Meulders, D.; Wilkin L. (1991): Labour market flexibility: Critical introduction to the analysis of a concept, Labour market flexibility, Discussion Papers, International Labour Organisation, Geneva, pp. 1-13. 
Niebuhr, A and Herwartz, H.. (2011); Growth, Unemployment And Labour Market Institutions: Evidence From A Cross-Section Of EU Regions; Applied Economics; Vol. 43, No. 30, pp. 4663-4676;

Pissarides, Christopher A., 1994. Search Unemployment with On-the-job Search, Review of Economic Studies, Oxford University Press, vol. 61(3), pages 457-475.

Pissarides C. (1993); Unemployment Consumption and Growth; European Economic Review, Vol. 37, No. 4, pp. 837-854;

Pissarides, C.A. (1990); Equilibrium Unemployment Theory; Oxford, Blackwell;

Pissarides, Christopher A, 1985. "Dynamics of Unemployment, Vacancies and Real Wages with Trade Unions, Scandinavian Journal of Economics, Wiley Blackwell, vol. 87(2), pages 386-403.

Ramsey F.P. (1928), A Mathematical Theory of Saving," Economic Journal, Vol. 38, No 152, pp. 543 559

Rapley J, 1997. Understanding Development: Theory and Practice in the Third World. UCL Press. London

Rizka Juita Rachim. 2013. Analisis Pengaruh Upah Minimum Provinsi, Pengeluaran Pemerintah, Investasi Swasta Dan Jumlah Penduduk Terhadap Pengangguran Terbuka Di Provinsi Sulawesi Selatan Periode 1996 - 2010. Jurusan Ekonomi Fakultas Ekonomi Dan Bisnis . Universitas Hasanuddin Makassar RI. Laporan Sosial Indonesia tahun 2007. Jakarta

Sener, Mehmet Fuat 2000. A Schumpeterian Model of Equilibrium Unemployment and Labor Turnover, Journal of Evolutionary Economics 10 (5),: 557-583.

Sukirno, Sadono. (2008). Makro Ekonomi. Raja Grafindo Persada. Jakarta.

Sukirno, Sadono. (2000). Makro Ekonomi Modern Perkembangan Pemikiran dari Klasik hingga Keynesian Baru. Raja Grafindo Persada. Jakarta

Sukirno, Sadono, 1994. Pengantar Teori Ekonomi Makro. Penerbit Raja Grafindo, Jakarta.

Susanti et al. (2007). Indikator-Indikator Makroekonomi. Lembaga Penerbit Fakultas Ekonomi Universitas Indonesia: Jakarta.

Solow R. (1956): A Contribution to the Theory of Economic Growth. "The Quarterly Journal of Economics", Vol. 70, No 1.

World Bank, 1995. World Development Report.

Yanti, Vika Novi. 2014. Analisis Faktor-Faktor Yang Mempengaruhi Tingkat Pengangguran Di Jawa Tengah Tahun 1991 Sampai 2011. Ekonomi Pembangunan Fakultas Ekonomi Dan Bisnis. Universitas Muhammadiyah Surakarta 